\title{
PELAYANAN KEMENTERIAN AGAMA TERHADAP PENGANUT AGAMA HINDU DI KOTA MANADO SULAWESI UTARA
}

\section{Religious Ministry Service to The Hindu in Manado North Sulawesi}

\author{
Saprillah \\ Balai Penelitian dan Pengembangan Agama \\ Jl. AP. Pettarani No.72 Makassar \\ Email: pepi_litbang@yahoo.com
}

Naskah diterima tanggal 30 April 2013. Naskah direvisi tanggal 7 Agustus 2013. Naskah disetujui tanggal 22 Agustus 2013

\begin{abstract}
Abstrak
Penelitian ini dimaksudkan untuk "melihat kembali" sistem pelayanan publik yang dilakukan oleh Kementerian Agama terhadap penganut agama "yang berjumlah sedikit". Asumsi dasarnya adalah bahwa problem minoritas terkadang mempengaruhi situasi keberpihakan otoritas yang mainstream. Metode penelitian adalah kualitatif dengan mengeksplorasi sebanyak mungkin data dari narasumber yang terkait. Baik dari pejabat Kementerian Agama sebagai supplier pelayanan maupun dari masyarakat Hindu sebagai stakeholder. Penelitian ini dilakukan di Kota Manado. Hasil penelitian menunjukkan bahwa Jenis pelayanan Pembimas bersifat supporting service, agensi, tidak melayani warga secara langsung. Representasi pelayanan Kemenag dilakukan oleh guru agama Hindu, penyuluh agama, dan lembaga keagamaan. Secara umum, pelayanan Kemenag (melalui Bimas dan Penyelenggara Hindu) secara umum sudah berjalan dengan baik. Kedua unit kerja ini bekerja untuk memenuhi tugas pokok dan fungsi (tupoksi). Program kerja yang disusun setiap tahunnya dimaksudkan untuk memenuhi tupoksi pendidikan dan urusan agama Hindu (selain fungsi administrasi). Problemnya adalah soal transparansi dan partisipasi. Publik Hindu sebagai stakeholder sejauh ini tidak mengetahui dengan baik hal-hal apa yang menjadi program kerja yang diprogramkan oleh Kemenag. Ini karena partisipasi publik dalam penyusunan ataupun dalam pengambilan keputusan tidak terjadi. Kemenag "menjauhkan diri" dari publik karena menganggap sudah tahu apa yang dibutuhkan oleh publik. Kemenag hanya mengembangkan sistem yang bersifat empati.
\end{abstract}

Keywords: pelayanan, pembimas, masyarakat Hindu

\begin{abstract}
Research aims to review the system of religious ministry public service for the minority. Research was qualitative. Data gained from religious ministry officers as service supplier and from Hindu community as stakeholder in Manado. Result shows that the religious ministry did not serve the community directly. Its representative, namely Hindu teachers, religious proselytizer, and religious institution performed the service. Their service generally runs well. They run the program based on their prescribed duties and function and each year, activities are planned to implement the program. However, the program was lack of transparency and community participation. The Hindu community as stakeholders was not well informed about the program. The religious ministry office did not involve community in the program planning and decision making. They isolated themselves from the public and seemed to judge themselves know the need of the public.
\end{abstract}

Keywords: service, guidance, hindu

\section{PENDAHULUAN}

A sumsi dasar penelitian ini adalah orangorang yang berjumlah sedikit atau lazim disebut minoritas biasanya memiliki ruang ekspresi yang relatif lebih kecil dibandingkan dengan mereka yang berjumlah besar. Kelompok yang berjumlah sedikit biasanya harus berjuang lebih keras untuk mengekspresikan identitas dan diri mereka. Contoh kecilnya adalah pendirian 
rumah ibadah. Di daerah yang kebanyakan muslim misalnya gereja menjadi persoalan (misalnya GKI Yasmin di Bogor). Di daerah yang mayoritas Kristen, masjid menjadi persoalan (misalnya mesjid raya di Papua Barat). Hasil penelitian Tim Peneliti Balai Litbang Agama bidang Kehidupan tahun 2011 tentang penganut Agama Khonghucu menunjukkan kecenderungan serupa. Hak eksistensial umat Khonghucu menjadi problematik meski negara sudah memberi ruang politik yang sama dengan agama lain, misalnya tidak tercatat dalam statistik di beberapa kementerian. Lagi-lagi, karena jumlah yang sedikit.

Dalam kasus Hindu di Kota Manado, asumsi tentang pengabaian kelompok minoritas semakin menguat di otak saya ketika kesulitan menemukan spanduk penyambutan Hari Nyepi di areal publik yang jatuh pada tanggal 09 Maret 2013. Spanduk ucapan selamat Nyepi hanya terlihat di Kantor Kementerian Agama dan spanduk ucapan dari Walikota Manado di Jalan 17 Agustus serta ucapan selamat dari BKSUA di Pura Jaghadgita Kelurahan Taas. Sangat berbeda ketika saya datang lagi pada Bulan April. Saya mudah menemukan spanduk ucapan selamat Paskah di sudut-sudut jalan Kota Manado meski hari Paskah sudah berlalu sekitar dua minggu.

Spanduk sebenarnya hanyalah representasi artifisial, simbolik tetapi cukup untuk digunakan sebagai penanda atas kode tertentu. Minimnya spanduk penyambutan Hari Nyepi tentu sangat berkaitan dengan jumlah orang Hindu yang sangat sedikit. Semua ini menegaskan kalau umat Hindu adalah umat yang minoritas (dari segi jumlah). Karena itu sangat memungkinkan warga Kota Manado non-Hindu tidak banyak tahu keberadaan umat Hindu di kota ini. Salah satu contoh adalah seorang tukang ojek yang mengantar peneliti ke pantai MBH (Manado Beach Hotel), tempat upacara Mlasti (salah satu rangkaian kegiatan Nyepi) dilaksanakan. Si tukang ojek yang sudah puluhan tahun tinggal di Kota Manado mengaku tidak tahu kalau ada orang Hindu. Dia tidak pernah punya teman yang berasal dari Bali (representasi orang Hindu di Indonesia). Dan ketika ikut menyaksikan upacara Mlasti, dia mengaku baru pertama kali ini tahu dan bertemu orang Hindu. Apalagi dalam jumlah banyak. Sekitar 500 orang. Setahunya, orang Hindu itu hanya ada di Bolaang Mongondow dan sekitarnya.

Eksistensi kelompok minoritas menjadi salah satu persoalan negara kontemporer. Demokrasi (subtantif) mengandaikan semua elemen sosial mendapatkan perlakukan (politik) yang sama. Negara wajib melayani seluruh elemen negara secara adil dan bijak. Refleksi tentang ini terlihat dengan jelas di sila kelima dasar negara Indonesia, keadilan sosial bagi seluruh rakyat Indonesia. Tetapi dalam banyak kasus, kelompok mayoritas seringkali berkehendak kuat untuk menjadi representasi tunggal atas nama "jumlah yang banyak" itu. Contoh yang paling riil adalah isu negara Islam yang menjadi perdebatan cukup panjang di Indonesia. Memang, para pendiri bangsa pada akhirnya sepakat untuk tidak memilih negara Islam dan "mengalah" atas nama kepentingan bersama tetapi perdebatan tentang itu terus menerus menjadi wacana yang setiap saat muncul. Kelompok Islam secara natural merasa punya hak untuk menjadikan negara ini sebagai negara Islam karena memiliki jumlah yang sangat banyak, kurang lebih $80 \%$ dari total jumlah penduduk di negara ini.

Pertanyaan terpenting dalam relasi ini adalah bagaimana negara dalam hal ini Kementerian Agama (Kemenag) melayani kepentingan orang-orang dalam kelompok minoritas ini? Apakah identitas sebagai kelompok minoritas mempengaruhi subtansi dan sistem pelayanan keagamaan? Ataukah sebaliknya? Negara sangat aware terhadap kelompok minoritas itu? Hal inilah yang menjadi fokus penelitian ini. Pertanyaan tersebut merupakan latar dari penelitian yang telah dilakukan dan menjadi artikel. Penelitian yang mencoba menggambarkan dinamika dan problematika masyarakat di Manado, pelayanan Kementrian Agama terhadap mereka dan tanggapan mereka terhadap pelayanan tersebut.

Untuk menjawab pertanyaan tersebut, dilakukan pengumpulan data dengan dengan cara konvensional metode kualitatif, yaitu wawancara dan observasi ditambah pengumpulan dokumen yang terkait dengan tema penelitian. Wawancara dilakukan setelah melakukan pemetaan terhadap subyek yang layak diwawancarai. Berdasarkan peta sosial yang ada, subyek yang kami anggap layak untuk diwawancarai adalah pejabat Kementerian Agama sebagai subyek yang melakukan pembinaan dan Hindu Kota Manado sebagai sasaran pembinaan.

Dari unsur Kemenag, wawancara dilakukan dengan pak Nengah Kokog (Kepala Pembimas Hindu), pak Made Suda (Penyelenggara Bimas Hindu/Buddha di Kemenag Kota Manado), $\mathrm{Ni}$ Kadek Novianti (Dari unsur masyarakat, saya mewawancarai pak Ida Bagus Putu Wedha Manuaba (Sesepuh Masyarakat Hindu), Ida Bagus 
Ketut Alit (Ketua Peradah Hindu Kota Manado), Tjok Trisnawati (Guru Agama Hindu), Ketut Surtha (Pemangku Agama Hindu), dan Dewa Ayu Indrayani (Pemuda/Mahasiswa Hindu).

\section{PEMBAHASAN}

\section{Masyarakat Hindu di Kota Manado; Minoritas} yang Gembira?

"Saya bangga menjadi orang Bali walau saya lahir disini, bukan di Bali. Saya tidak minder memakai kebaya orang Hindu Bali untuk sembahyang di Pura". Satu kalimat meluncur dari mulut seorang mahasiswi Bali transmigran yang kuliah di FKM (Fakultas Kesehatan Masyarakat) Universitas Sam Ratulangi, bernama Dewa Ayu Indrayani. Kalimat sederhana ini menjadi refleksi bagaimana orang-orang Hindu di Kota Manado bebas merayakan dirinya sebagai penganut Hindu. Ekspresi kebebasan ini terlihat jelas bagi saya ketika menyaksikan komunitas Bali di Manado dengan bebas membunyikan gong di atas mobil arakarakan yang membawa sesajen dari Pura Jaghadgita di Taas menuju Pantai MBH (Manado Beach Hotel) untuk kepentingan perayaan upacara mlasti, salah satu rangkaian ibadah Nyepi. Jarak antara pura dan pantai $\mathrm{MBH}$ relatif jauh. Sepanjang jalan itu, gong ditabuh dan menjadi tontonan warga yang dilalui.

Warga Hindu yang tinggal tersebar di berbagai tempat di Kota Manado berdatangan ke pantai dengan pakaian adat khas Bali (lelaki memakai sarung selutut dan tutup kepala, sedangkan perempuan menggunakan sarung semata kaki dan kebaya). Mereka datang dengan wajah yang ceria. Di Tondano, mahasiswa Unima (Universitas Negeri Manado) yang beragama Hindu menggelar pawai patung Ogoh-Ogoh. Patung Ogoh-ogoh yang merupakan simbol kejahatan diarak melewati jalan utama menuju ke Pura Danum Manda, Tondano. (Padahal, pawai patung Ogoh-Ogoh sangat jarang dilakukan oleh masyarakat di luar Bali) (Manado Post, 13 Maret 2013). Di Unima Tondano memang ada banyak mahasiswa beragama Hindu yang berasal dari berbagai daerah di Kawasan Timur Indonesia karena di sana ada Prodi (Program Studi) Agama Hindu.

Ekspresi kegembiraan warga Hindu merayakan kebebasan beragamanya adalah sesuatu yang patut diapresiasi. Kota Manado(Sulut pada umumnya) memang dikenal sebagai wilayah tingkat relasi antar umat beragama yang sangat baik $(0,79$ atau sangat baik berdasarkan Laporan Tim Peneliti Balai Litbang Agama Makassar Bidang Kehidupan,
2011). Idiom budaya torang samua basudara benarbenar dipraktikkan oleh warga Manado. Pada hari besar masing-masing agama, praktik saling mengunjungi masih mudah ditemukan. Misalnya pada saat peringatan Nyepi kemarin. Warga kota Manado non-Hindu menyempatkan diri untuk mengunjungi tetangga dan kolega mereka yang beragama Hindu untuk makan bersama merayakan hari Ngembak Geni (menghidupkan api kembali). Begitupula, pada saat hari raya Natal dan Idul Fitri. Saling mengunjungi untuk membangun hubungan antar umat beragama masih terjaga dengan baik. Orang Manado sangat berbangga diri dengan citra kerukunan yang melekat pada mereka.

Citra ini bersumber pada dua hal, pertama identitas keminahasaan sebagai identitas utama memiliki karakter terbuka, damai, dan adaptif. Identitas Minahasa memang dijadikan sebagai lapisan utama identitas diri orang Sulawesi Utara. Mereka sangat meyakini karakter budaya Minahasalah yang menyebabkan seluruh pendatang merasa welcome dan nyaman untuk tinggal di daerah ini. Kedua, relasi kekerabatan antar kelompok agama terjalin dengan kuat. Masyarakat Sulawesi Utara memang relatif unik. Proses perkawinan lintas agama kerap terjadi dan membentuk jaringan kekerabatan yang multi agama. Hasil penelitian Balai Litbang Makassar tahun 2009 menyebutkan 4 dari 10 orang Manado memiliki kerabat inti (saudara, orang tua, dan sepupu) yang berbeda agama. Jalinan persaudaraan lintas agama ini merupakan modal sosio-kultural yang sangat kuat untuk membentuk persaudaraan sosial yang lebih luas. Setidaknya, pola relasi kekerabatan seperti ini dapat meminimalisir konflik (Tim Peneliti Bid. Kehidupan Beragama, 2011: 48).

Kehadiran masyarakan Hindu di Kota Manado relatif baru. Pendatang Bali yang beragama Hindu mulai datang ke kawasan Sulut pada tahun 1960an. Kedatangan orang Bali secara massif di Sulut tidak bermula di Manado tetapi di Bolaang Mongondow (saat itu belum terbagi menjadi empat kabupaten/kota). Pada tahun 1963, Gunung Agung meletus. Beberapa desa di sekitar gunung itu terpaksa diungsikan. Bupati Bolaang Mongondow, Kapten Danolii, berinisiatif menghadap Gubernur Bali, Sutejo untuk meminta penduduk di sekitar Gunung Agung yang menjadi korban untuk ditransmigrasikan ke wilayahnya. Gelombang pertama menempati tanah kosong yang sekarang dikenal dengan nama Desa Wardhi Agung. Setahun kemudian (tahun 1964) datang lagi rombongan 
transmigran dan ditempatkan di sebuah lahan kosong yang sekarang dikenal dengan nama Desa Kembang Merta. Sepuluh tahun kemudian atau tepatnya pada tahun 1974, datang lagi gelombang transmigran dalam jumlah yang relatif banyak dan ditempatkan di dua lahan kosong yang kemudian dikenal dengan nama Desa Mopuya dan Desa Mopugan. Penduduk Hindu dari daerah Bolmong inilah kemudian yang menyebar ke Manado. Selain, para pendatang dari Bali dan Jawa yang bekerja di sektor formal (pegawai kementerian lembaga dan instansi pemerintah) atau di sektor informal (wawancara IBP Wedha Manuaba, 10/3/2013).

Komunitas Hindu di Kota Manado saat ini sebagian besar berasal dari desa-desa transmigran. Generasi kedua transmigran yang sudah lahir di Sulawesi Utara menjadikan Manado sebagai tujuan untuk melanjutkan pendidikan. Mereka kemudian mencari pekerjaan dan menetap di Manado lalu membentuk komunitas warga Hindu. Persebaran warga Hindu transmigran sudah mulai berlangsung sejak tahun 1970an hingga sekarang. Mereka bergabung dengan umat Hindu lain yang sudah ada di Manado dan yang terus berdatangan dari berbagai daerah di luar Sulawesi Utara. Melihat banyaknya mahasiswa Bali yang kuliah, para tokoh Hindu menginisiasi pembangunan asrama (pasraman) mahasiswa Bali dan mendirikan pura di dekatnya sebagai pura pertama di Manado pada tahun 1981. Setelah semakin berkembang, para tokoh Hindu berusaha mencari tanah pada tahun 1984 dan mulai membangun Pura Jaghadgita pada tahun 1990 sebagai pusat ibadah orang Hindu di Manado. Pembangunan dilakukan secara bertahap sampai sekarang. Pura ketiga dibangun pada tahun 2010 dan diresmikan pada tanggal 27 Maret 2013 lalu dengan mengadakan persembahyangan bulan purnama. Pura ini terletak dalam kawasan Rumah Sakit Umum Manado yang berada di Malalayang.

Berdasarkan Data Kementerian Agama Kota Manado tahun 2011, jumlah umat beragama di Kota Manado sebanyak 506.137 jiwa. Umat Kristen sebanyak 290.665, umat Islam sebanyak 175.569, Katolik, 30275, Buddha 6.436, dan Khonghucu sebanyak 600 jiwa. Sedang umat Hindu berjumlah 2.592 dan tersebar di berbagai tempat. Tidak ada tempat di Manado yang bisa disebut sebagai representasi orang Bali (Hindu). Seperti Kampung Kodok, Komo Luar, dan Kampung Arab yang dikenal sebagai basis umat Islam. Di Kelurahan Taas, tempat Pura Jaghadgita berdiri pun memang ada sekitar 20 KK orang Hindu yang menetap. Namun, wilayah itu dikenal sebagai basis umat Kristiani bukan wilayah representasi orang Hindu atau Bali. Pola pemukiman unsegregated itu terjadi karena pendatang Bali ini datang ke Manado tidak dalam koloni yang besar, bahkan cenderung individual. Berbeda dengan kedatangan para transmigran Bali di Bolmong yang datang dalam jumlah besar. Mereka dengan mudah dapat diasosiasikan dengan wilayah tertentu di sana seperti Desa Kembang Merta dan Wardhi Agung yang dikenal sebagai desa orang Bali. Dan lagi pula, pada tahun 1970an (saat dimulainya arus orang Bali Hindu masuk ke Kota Manado), pemukiman di Kota Manado relatif sudah terbentuk sebagaimana yang kita kenal sekarang. Pemukiman baru yang terbentuk tidak lagi terafiliasi dalam identitas kelompok tertentu tetapi sudah menjadi perkumpulan yang tercampur baik suku maupun agama.

Jumlah Umat Hindu di Sulut secara keseluruhan sebanyak 20.960. Basis terbesarnya di Bolaang Mongondow sebanyak 14.996 atau 71,6 \% dari total umat Hindu di Sulut. Kedua di Manado sebanyak 2.592 atau $12.4 \%$. Selanjutnya, di Bitung sebanyak 1.434 atau 6,8 \% dan Kotamobagu sebanyak 1.225 atau 5,8 \%. Sedangkan untuk kabupaten lainnya jumlah orang Hindu di bawah 500 orang. Bahkan di beberapa kabupaten tidak sampai sepuluh orang (Pembimas Hindu Kanwil Kemenag Provinsi Sulawesi Utara, 2012.)

Masyarakat Hindu Manado adalah potret dari kelompok minoritas yang gembira. Jumlah yang sedikit tidak mempengaruhi mereka untuk tidak bebas merayakan identitas agamanya. Mereka tidak pernah mengalami seperti apa yang dialami oleh masyarakat Kristen di Bogor yang kesulitan mendirikan rumah ibadah (kasus Gereja Yasmin) atau seperti masyarakat muslim di Manokwari yang pendirian masjid raya ditentang oleh masyarakat sekitarnya. Pendirian pura berjalan dengan lancar. Bahkan salah satu pura yang berada di kawasan rumah sakit umum (di daerah Malalayang) didirikan karena bantuan tanah dari pihak rumah sakit. Bantuan yang diberikan kepada semua agama, sehingga di kompleks itu ada lima rumah ibadah yang berdekatan. Pura Jaghadgita yang merupakan pusat ibadah umat Hindu Manado berdiri persis di belakang Gereja Salib Suci. Menurut Ketut Dewa Anom (Ketua Parisada Hindu Provinsi Sulut) bahwa di Tondano ada sebuah pura yang dibangun (tahun 1993) meski di sekitar tempat itu sama sekali tidak ada warga Hindu (wawancara Ketut Dewa Anom, 21/4/2013). Yang menjaga pura itu sekarang adalah 
orang Minahasa yang beragama Kristen Semuanya berjalan dengan normal tanpa ada ancaman gangguan sedikit pun. Secara sekilas, masyarakat Hindu di Manado tidak masuk dalam kategori yang sebagai "minoritas" yang harus disingkirkan karena bisa menggerogoti kepentingan dan eksistensi kelompok mayoritas.

Sanderson (2000:380) menyatakan bahwa kelompok minoritas adalah kelompok yang mempunyai karakteristik pokok; minoritas timbul dalam batas-batas suatu masyarakat negara yang lebih besar; anggota-anggota dapat dibedakan secara fisik ataupun secara budaya dari anggotaanggota kelompok lainnya dalam masyarakat yang sama, dan minoritas ini sampai tingkat tertentu mengalami perlakukan yang tidak sama dan tidak adil dalam tangan kelompok-kelompok lainnya itu. Kelompok lainnya, yang memberi perlakuan yang tidak sama kepada kelompok-kelompok minoritas, biasanya disebut kelompok mayoritas.

Mengapa warga Hindu bisa hidup nyaman sebagai minoritas di kota Manado? Pertanyaan ini cukup menggelitik mengingat relasi mayoritasminoritas di beberapa daerah di Indonesia menunjukkan fenomena yang mengkhawatirkan. Saya mengasumsikan beberapa faktor yang mempengaruhi hal itu. Pertama, orang Hindu mulai datang ke Manado ketika kesadaran akan pentingnya hidup dan bekerja sama antar umat beragama mulai dibangun dengan munculnya BKSAU (Badan Kerja Sama Antar Umat Beragama) pada tahun 1958. Organisasi yang menghimpun semua kekuatan sosial dari semua agama adalah refleksi tokoh-tokoh agama di Sulut akibat adanya rusuh sosial yang melibatkan umat Islam dan Kristen pada akhir tahun 50 an. Konflik ini bermula dari perselisihan personal antar seorang Gorontalo Muslim dan China Kristen. Konflik ini kemudian meluas menjadi konflik antar umat Islam dan Kristen. Ada banyak rumah ibadah yang terbakar. Setelah kejadian itu, tokoh-tokoh masyarakat bersepakat untuk mengikat diri dalam satu wadah yang disebut dengan BKSAU itu. Organisasi ini menarik karena representasi agama tidak mengenal persentasi. Semua agama ada perwakilannya dengan jumlah yang sama. Di tingkat kabupaten/ kota semua agama diwakili satu orang. Di tingkat provinsi semua agama diwakili oleh empat orang.

Kedua, para transmigran Bali secara umum tidak rese. Orang-orang Bali datang ke Manado dengan spirit bekerja. Menurut Pak Wedha, ada dua budaya yang cukup dikenal sebagai representasi orang Bali secara umum. Budaya kerja keras dan koh ngomong (tidak banyak bicara). Kedua budaya ini membuat orang Bali mudah beradaptasi dengan lingkungan. Budaya koh ngomong misalnya membuat orang Bali cuek dan enggan mengurusi urusan orang lain (wawancara IBP. Wedha Manuaba, 13/4/2013).

Ketiga, pola pemukiman warga Bali di Manado tidak terpusat pada satu titik tertentu tetapi menyebar. Dengan pola demikian, warga Hindu dituntut untuk lebih adaptif dengan lingkungannya. Secara teoritik, skala konflik bisa semakin meluas ketika munculnya solidaritas warga yang berada di pemukiman yang tersegregasi. Seperti yang dikatakan oleh Pak Ketut Alit, "Ya mungkin karena kami menyebar pak ya. Biasanya kalau ada konflik terjadi di kompleks tertentu. Kami di sini (Manado) tidak ada kompleks orang Bali atau Hindu" (wawancara Ida Bagus Ketut Alit-Ketua Parisada Kota Manado, 14/4/ 2013).

Keempat, akibat dari kurangnya populasi orang Hindu adalah melambatnya pembangunan rumah ibadah. Berkaitan dengan hal ini, Ida Bagus Ketut Alit mengatakan bahwa, mereka (terpaksa) menolak pembangunan Pura yang ditawarkan oleh pihak TNI dan Kepolisian karena kekhawatiran tidak bisa memelihara keberlangsungan Pura tersebut sebagai akibat dari kurangnya populasi mereka (wawancara, 14/4/2013). Tiga pura yang ada di Kota Manado dianggap cukup untuk memenuhi kebutuhan beribadah umat Hindu khususnya ibadah purnama-tilem, hari Saraswati, atau tawur kesangeh, dan untuk dijadikan sebagai tempat pelaksanaan sekolah minggu. Dengan pembangunan rumah ibadah yang lambat, masyarakat Hindu tidak memiliki pengalaman soal kesulitan membangun rumah ibadah, khususnya pasca terbitnya PBM No.9 dan 8 tahun 2006.

Kelima, spirit nilai agama Hindu yang mengedepankan harmonisasi hubungan ikut pula menjadi faktor penting dalam strategi adaptasi orang Hindu. Salah satu ajaran Hindu yang mendasar adalah konsep tat wam asi. Konsep teologis ini mengandaikan seluruh manusia pada prinsipnya berasal dari atman (jiwa) yang satu dan karena itu manusia pada prinsipnya adalah satu. Tat wam asi biasa diterjemahkan saya adalah kamu. Atman yang ada dalam tubuh saya adalah juga atman yang ada dalam tubuhmu. Spirit ini menjadi modal sosial yang sangat penting untuk hidup bersama dalam konfigurasi sosial yang beraneka ragam seperti Kota Manado. 


\section{Problematika Umat (Sebagai Kelompok Minoritas)}

Meski saya kategorikan sebagai minoritas yang gembira, namun tidak berarti masyarakat Hindu tidak memiliki problem keagamaan yang terkait dengan realitas mereka sebagai masyarakat yang berjumlah sedikit. Kasus yang paling mencolok adalah sulitnya orang Hindu merayakan Nyepi sebagaimana mestinya. Orang Hindu Manado tidak bisa dengan nyaman melaksanakan ibadah Nyepi karena situasi sosialnya tetap ramai. Tidak ada perlakuan khusus bagi umat Hindu Manado seperti yang dirasakan di Bali atau di desa berbasis umat Hindu di Bolaang Mongondow. Tentu saja ini sulit karena soal pesebaran umat Hindu Manado yang sangat sedikit dan tersebar di beberapa tempat. Berbeda dengan umat Hindu di empat desa (Wardhi Agung, Kembang Merta, Mopuya, dan Mupogad) di Kecamatan Domuga, Kab. Bolaang Mongondow, suasana Nyepi benar-benar terasa karena jalan-jalan utama di desa tersebut ditutup. Masyarakat nonHindu pun ikut "Nyepi" dengan tidak melakukan aktivitas kehidupan yang berarti (Manado Post, 13/3/2013).

Pilihan satu-satunya adalah menerima keadaan itu dan memberi makna baru, seperti yang diungkapkan oleh Nengah Kokog:

Tentu sangat berbeda pak ya. Kalau di Bali semua elemen terlibat dalam Nyepi. Tidak ada aktivitas hari itu, tidak ada penerbangan padahal disana penerbangan internasional. Mall tidak boleh buka. Pokoknya semua ikut merasakan. Mungkin karena disana kami mayoritas jadi pemerintah lebih mudah membuat kebijakan misalnya dengan meminta PLN mematikan aliran listrik selama satu hari. Tetapi saya menilai, Nyepi di luar Bali bisa lebih terasa karena tantangannya sangat berat. Seperti saya bilang. Kita kan hidup di tengah banyak orang. Apalagi jumlah kami sedikit. Tetapi nilainya lebih ada. Artinya kita lebih sadar untuk mematikan lampu. Bedakan di Bali mau tidak mau harus mau karena listrik memang sudah dimatikan. Artinya ada unsur luar yang ikut mempengaruhi Nyepi. Kalau disini benar-benar kesadaran pribadi untuk mematikan lampu (wawancara, 8/3/2013).

Bagi Pak Nengah Kokog, perayaan nyepi di Manado mendorong kesadaran keagamaan yang jauh lebih tinggi. Kesadaran yang muncul dari refleksi keagamaan bukan kesadaran mekanis yang secara struktural didorong oleh situasi lingkungan seperti di Bali. Nyepi di Bali memiliki dimensi mekanik karena konstruksi sosial seluruhnya dipengaruhi oleh lingkungan sosial. Bahkan, orang-orang non Hindu sekalipun terpaksa ikut nyepi karena seluruh layanan publik yang komersil maupun non komersil ditutup.

Pemikiran Pak Nengah adalah bentuk kode ulang pemaknaan ritual yang berbasis pada situasi sosial. Situasi minoritas justru dijadikan spirit untuk memaknai dan menjalani ritual dengan cara yang baru. Bentuk pemaknaan ini penting untuk menghindarkan mereka dari cara berfikir "menyalahkan orang lain" dan menjadi bagian dari strategi adaptasi dengan situasi sekitar.

Problem yang paling terasa bagi umat Hindu di Kota Manado adalah layanan pendidikan agama untuk anak-anak mereka. Guru agama Hindu yang berstatus PNS saat ini hanya ada satu orang. Itu pun bertugas di Sekolah Dasar, dan karena sistem sertifikasi mewajibkan seorang guru mengajar selama $24 \mathrm{jam}$, sang guru pun "terpaksa” hanya mengajar di satu sekolah saja (SDN 11). Hanya anakanak Hindu yang belajar di sekolah itu (termasuk SDN 6 yang satu kompleks dengan SDN 11) diberi pengajaran agama Hindu secara rutin. Anak-anak Hindu yang sekolah di level SMP dan SMA tidak memiliki guru agama sama sekali.

Untuk memenuhi kebutuhan pendidikan bagi anak-anak, masyarakat Hindu melalui sebuah yayasan mengelola sekolah minggu. Sekolah minggu yang bertempat di sebuah aula sederhana di kawasan Pura Jaghadgita berfungsi sebagai sekolah agama alternatif. Sekolah ini sangat penting baik secara subtantif maupun secara administratif. Secara subtantif, sekolah minggu menjadi tempat pembekalan nilai-nilai agama Hindu bagi generasi muda mereka. Sedangkan secara administratif, sekolah minggu menyuplai nilai agama bagi anakanak Hindu di sekolah mereka masing-masing. Pernah ada kasus seorang siswa terancam tidak naik kelas karena tidak ada nilai agama di buku rapornya dan anak itu tidak ikut sekolah minggu. (Ketut Dirtha-tokoh masyarakat dan pegawas pendidikan agama Hindu, 12 /4/2013) Dengan demikian, peran sekolah minggu menjadi sangat penting bagi masyarakat Hindu di Kota Manado.

Sekolah Minggu ini sudah dilaksanakan sejak tahun 1978 atas inisiasi Gusti Agung Sutiasa (Pembimas Hindu/Buddha Kanwil Depag Sulut) dan I Ketut Genah (Ketua PHDI pertama Sulut). Kepentingan utamanya adalah memberikan pendidikan keagamaan bagi generasi muda Hindu yang tidak didapatkan di sekolah formal. Sebelum Pura Jaghadgita berdiri, sistem sekolah minggu dilakukan secara bergiliran dari rumah ke rumah. 
Namun, setelah Pura berdiri pada tahun 1990, konsentrasi sekolah minggu dipusatkan di Pura.

Sekolah minggu adalah solusi tetapi berdampak pada hak libur warga Hindu terutama para guru, anak-anak, dan orang tua yang anakanaknya ikut program sekolah minggu. Mereka tidak bisa menikmati hari libur dengan leluasa karena masih disibukkan dengan sekolah minggu. Berkaitan dengan itu, dua atau tiga tahun terakhir atas masukan orang tua siswa, pihak yayasan mengeluarkan kebijakan hanya melakukan pengajaran selama tiga kali hari minggu. Hari minggu terakhir setiap bulannya diliburkan (wawancara Ketut Dirtha, 12/4/ 2013).

Hal yang cukup "memiriskan" adalah fakta bahwa setiap tahun UAS (Ujian Akhir Sekolah) SD, anak-anak Hindu di beberapa sekolah sering tidak mendapatkan soal agama. Padahal, menurut pak Ketut Dirtha, pendataan anak sudah dilakukan dan disetor kepada pihak dinas pendidikan. Untuk mengantisipasi itu, pak Ketut Dirtha bekerja ekstra untuk menggandakan soal yang ada di sekolah tertentu (yang mendapatkan soal ujian) untuk didistribusikan kepada anak-anak Hindu yang tidak mendapatkan soal. Tidak adanya soal ujian tersebut berkaitan dengan jumlah anak Hindu yang tersebar di beberapa sekolah. Tak jarang di satu sekolah hanya ada satu orang anak Hindu. Akibatnya, pada pengepakan soal ujian kadang-kadang soal ujian agama Hindu diabaikan atau lupa disisipkan dalam kantong soal (wawancara Ketut Dirtha, 12/4/2013).

Kelalaian ini tentu saja bukan bagian dari mekanisme politik yang secara sengaja meminggirkan tetapi bentuk "ketidaktelitian" karena jumlah yang tidak banyak.

\section{Memasuki Halaman Pelayanan Kementerian Agama}

Ada dua pintu pelayanan yang disediakan oleh Kemenag bagi masyarakan Hindu di Sulut (khususnya di Manado), Pembimas Hindu di tingkat Kanwil Provinsi Sulut dan Penyelenggara Bimas Hindu (dan Buddha) di tingkat Kemenag Kota Manado. Struktur Pembimas di tingkat Kanwil sudah ada sejak tahun 1978. Gusti Agung Sutiasa dikenal oleh masyarakat Hindu sebagai Pembimas Hindu/Buddha pertama di Kemenag Provinsi Sulawesi Utara. Pada tahun 2006, mengikuti kebijakan Departemen Agama RI, Pembimas Hindu dan Buddha dipisahkan. Sedangkan struktur Penyelenggara Bimas Hindu/Buddha di Kemenag Kota Manado ada sejak tahun 2002 sebagai implementasi dari KMA 373 tahun 2002. Struktur ini tidak berubah meski telah terbit PMA No. 13 tahun 2012.

Dua struktur Bimas tersebut adalah perpanjangan dari Direktorat Jenderal Bimas Hindu di Kementerian Agama RI. Karena itu, visi dan misi mereka adalah penjabaran dari visi dan misi Dirjen Bimas Hindu dengan tambahan geografi tempat struktur (lokal) itu berada. Visi Bimas Hindu Sulut adalah "terwujudnya masyarakat Provinsi Sulawesi Utara yang taat beragama dan harmonis". Sedangkan misinya adalah 1) meningkatkan kualitas bimbingan, pemahaman, pengamalan, dan pelayanan kehidupan; 2) meningkatkan kualitas pendidikan agama dan keagamaan Hindu; 3) memberdayakan lembaga sosial keagamaan dan lembaga pendidikan keagamaan Hindu; 4) memperkokoh kerukunan umat beragama Hindu; 5) mengembangkan seni dan budaya serta keselarasan pemahaman keagamaan Hindu.

Kehadiran unit kerja Bimas Hindu sejak tahun 1978 dan Penyelenggara Hindu tahun 2002 adalah bentuk "pemenuhan hak yang sama" oleh negara terhadap warga Hindu yang ada di Sulawesi Utara. Setidaknya melalui, unit kerja ini, kepentingan warga Hindu dalam konteks keagamaan mempunyai lokus dalam negara. Artinya, sebagai kelompok warga yang berjumlah sedikit atau minoritas telah mendapatkan representasi dan rekognisi dalam struktur lembaga negara.

Problemnya adalah penempatan unit kerja (khususnya penyelenggara Hindu di tingkat Kementerian Agama Kota) salah tempat atau tidak memenuhi standar reliability (tepat sasaran). Dalam konteks Sulawesi Utara, basis umat Hindu adalah Kabupaten Bolaang Mongondow. Ada 14.000 warga Hindu di wilayah itu. Seharusnya penyelenggara Bimas Hindu ditempatkan di wilayah itu, bukan di Kota Manado yang jumlah warganya "hanya" 2000-an jiwa. Penempatan yang asal-asalan ini menunjukkan adanya persoalan pengambilan keputusan yang tidak berbasis realitas kemasyarakatan.

Problem lain yang berkaitan dengan poin ini adalah integrasi Agama Hindu dan Buddha dalam satu unit kerja, penyelenggara Hindu dan Buddha. Hal ini tentu saja berpengaruh pada sistem pelayanan. Hal ini sudah terjadi sejak KMA 373 tahun 2002. Keadaan struktural ini tidak berubah meski telah muncul peraturan baru PMA No.13 tahun 2012. Penyelenggara Hindu dan Buddha tetap disatukan dalam satu unit kerja. Hal ini bisa dibaca sebagai bentuk "pengabaian" hak kelompok 
agama ini untuk dilayani secara baik. Apalagi, jika hal ini dikaitkan dengan munculnya unit kerja baru di Kemenag yaitu "penyelenggara Syariah" untuk agama Islam. Padahal, secara struktural Dirjen Bimas Hindu dan Buddha sudah terpisah sejak tahun 2006. Demikian pula, Bimas Hindu dan secara struktural Dirjen

Bimas Hindu dan Buddha yang sudah dipisahkan.

Untuk mengetahui kualitas pelayanan Bimas Hindu Kemenag Prov. Sulut, ada baiknya melihat program kerja yang disusun oleh Bimas Hindu untuk tahun kerja 2012, (Dikutip dari Rencana Kinerja Tahun 2012 Bimas Hindu Provinsi Sulawesi Utara) yaitu program di Bidang Pendidikan Agama Hindu, memprogramkan peningkatan mutu Pendidikan Agama Hindu dengan memberikan honorarium kepada tim sertifikasi jabatan Guru Agama Hindu; koordinasi, monitoring, dan evaluasi pendidikan (konsultasi program dan kegiatan ke pusat); melaksanakan pembinaan/monitoring dan evaluasi pendataan program dan kegiatan kabupaten kota; melaksanakan orientasi Guru Agama Hindu; melaksanakan workshop KTSP Guru Agama Hindu; menyelenggarakan Udsawa Dharma Gita Tingkat Provinsi; menyelenggarakan pasraman kilat; memberikan honor guru tidak tetap; memberikan bantuan biaya operasional yayasan/pasraman; melaksanakan kegiatan ajang prestasi Hindu; melaksanakan pengadaan perangkat pengolah daya dan komunikasi (laptop dan PC/ komputer); melaksanakan pengadaan dan fasilitas perkantoran (AC).

Program bidang urusan Agama Hindu untuk peningkatan kualitas pelayanan kehidupan beragama mengadakan orientasi manajemen kelembagaan Hindu; menyelenggarakan bimbingan dan dakwah Agama Hindu di televisi dan radio; menyelenggarakan dialog interaktif Keagamaan Hindu di televisi; mengadakan pembinaan penyuluh Agama Hindu Non PNS; melaksanakan pembinaan/Koordinasi dan konsultasi Pengawasan Kegiatan Agama Hindu; melaksanakan pembinaan/ koordinasi dan konsultasi pengawasan kegiatan Agama Hindu(monitoring pendataan Agama Hindu kab/kota); mengadakan bahan ATK pelaporan, fotokopi dan suplies computer; mengelola dan memberikan honorarium kepada pengelola kegiatan Agama Hindu; menyelenggarakan rapat kerja jajaran Bimas Hindu dan penyuluh Agama Hindu; memberikan subsidi tunjangan bagi penyuluh Agama Hindu Non PNS di Provinsi Sulut; memberikan bantuan pembangunan/rehabilitasi rumah Ibadah Hindu; memberikan bantuan sound system Pura; dan memberikan bantuan pakaian (busana) Pemangku.

Program kerja yang disusun oleh Bimas Hindu Kemenag Prov. Sulut setiap tahunnya memang dimaksudkan untuk memenuhi dua hal, yaitu: bidang pendidikan dan urusan umat. Dua hal yang menjadi tupoksi (tugas pokok dan fungsi) Bimas Hindu (selain urusan administrasi internal). Secara umum, program kerja yang dirancang oleh Bimas Hindu sudah cukup komprehensif dan sudah memenuhi tupoksi yang dibebankan kepadanya.

Model pelayanan Bimas Hindu adalah supporting service. Artinya, bentuk pelayanan tidak langsung tetapi bersifat pendukung. Bimas Hindu tidak melayani masyarakat Hindu secara langsung sebagaimana model pelayanan haji, pernikahan, dan atau pelayanan publik di kelurahan. pelayanan keagamaan Bimas Hindu dilakukan melalui agen yang direplikasi oleh guru agama, penyuluh agama, dan organisasi internal agama (Parisada, Perada, dan KMHDI). Program kerja yang disusun oleh Bimas Hindu di atas setidaknya telah menunjukkan bagaimana mereka telah berupaya untuk mendukung para agen dengan program penguatan kapasitas (sertifikasi guru, orientasi, dan workshop), bantuan financial, dan penyediaan sarana siar di TV dan radio.

Problemnya adalah sistem pelayanan supporting service membuat 'jejak pelayanan' Bimas Hindu di tengah masyarakatnya kurang terlihat. Misalnya, kita ambil contoh soal penyediaan tenaga pengajar agama Hindu. Sejauh ini, jumlah guru yang mengajar di Kota Manado hanya satu orang itupun hanya di tingkat SD. Untuk warga Hindu Manado, kehadiran guru agama adalah kebutuhan yang sangat penting untuk generasi mereka. Bimas dan Penyelenggara Hindu tidak mampu memenuhi kebutuhan umat tersebut. Mereka tidak pernah berhasil memperjuangkan untuk mendapatkan kuota pengangkatan guru agama sejak tahun 2000. Tentu saja, ini bukan kesalahan Bimas dan Penyelenggara Hindu sepenuhnya.

Sistem pengangkatan pegawai baru di kemenag bersifat nasional. Kuotanya ditentukan sepenuhnya oleh pusat. Menurut Made Suda (Kepala Penyelenggara Bimas Hindu/Buddha), usulan pengangkatan guru agama setiap tahun diusulkan ke pusat tetapi tidak pernah mendapatkan tanggapan (wawncara Made Suda, 16/4/ 2013). Salah satu faktornya adalah kurangnya jumlah warga Hindu di Kota Manado dan tidak adanya sekolah Hindu yang 
menjadi persyaratan pengangkatan tenaga pengajar. (wawancara Kadek Novianti, 18/4/2013).

Contoh lain adalah absennya jejak pelayanan Bimas Hindu di acara diskusi bulanan warga Hindu baik dalam bentuk dharma wacana (ceramah agama) maupun dalam bentuk persantian (diskusi agama). Kegiatan warga ini relatif berjalan lancar. Khususnya acara dharma wacana yang dirangkaikan dengan kegiatan arisan keluarga Bali. Masyarakat Hindu Manado membagi diri dalam tiga komunitas kecil yang disebut tempek. Tempek Tengah, Selatan, dan Utara. Setiap bulan komunitas ini menggelar kegiatan rutin. Ceramah agama sebagian besar disuplai oleh PHDI karena kegiatan ini memang merupakan program kerja dari PHDI Kota Manado. Bagi warga Hindu, kegiatankegiatan ini adalah kegiatan warga bukan bagian dari kegiatan Kementerian Agama (Bimas Hindu). Mereka tidak menyadari kalau beberapa orang yang terlibat sebagai narasumber atau pemberi ceramah agama adalah penyuluh honorer yang setiap bulan mendapatkan insentif dari Kemenag (meski memang tidak semuanya). Itulah resiko dari model pelayanan tidak langsung.

model pelayan tidak langsung atau supporting service merupakan pilihan yang paling rasional bagi Bimas Hindu. Sebagai salah satu unit negara yang bertugas untuk meningkatkan dan menguatkan kualitas keagamaan umat melalui pendidikan dan penyiaran agama, Bimas Hindu memiliki keterbatasan untuk melakukan pelayanan secara langsung. Sumber daya manusia dan sumber dana yang dimiliki sangat terbatas. Di Bimas Hindu hanya ada tiga staf yang sehari-hari ditugaskan untuk mengerjakan proses administrasi. Di Penyelenggara Hindu/Buddha Kemenag Kota lebih sedikit lagi, hanya ada satu staf, satu orang penyuluh (ini pun untuk Buddha), dan satu orang pengawas. Dari sisi anggaran tahunan, pun sangat minim. Dana yang disediakan oleh kementerian dianggap tidak mencukupi untuk melayani seluruh kebutuhan warga Hindu di Sulawesi Selatan. Ambil contoh dana yang ada di Penyelenggara Bimas Hindu/Buddha. Berdasarkan LAKIP tahun 2012, dana operasional penyelenggara Bimas Hindu/Buddha hanya tujuh puluh juta. Tidak banyak yang bisa dilakukan dengan anggaran seminim itu. Ada banyak usulan program yang pada akhirnya tidak bisa direalisasikan karena tidak mendapatkan supporting dana. Dengan realitas SDM dan dana seperti itu, memang sangat sulit mengharapkan Kemenag melalui Bimas dan penyelenggara Hindu untuk melakukan pelayanan secara langsung kepada masyarakatnya.
Pertanyaannya adalah apakah kualitas supporting service Bimas Hindu sudah baik? Ada dua cara yang bisa digunakan untuk menjawab pertanyaan ini. Pertama, mekanisme penyusunan program. Kedua, out put dan out come yang dihasilkan. Bagian kedua ini akan dijelaskan pada pembahasan selanjutnya.

Proses penyusunan program Bimas Hindu sejauh ini bersifat tertutup. Dalam arti, Bimas Hindu tidak melibatkan partisipasi masyarakat (atau setidaknya para agen terutama dari lembaga keagamaan masyarakat) secara langsung. Mekanisme penyusunan program hanya mengandalkan kemampuan personal pejabat Bimas Hindu dan staffnya. Untuk hal ini, Nengah Kokog sebagai Kepala Pembimas Hindu memiliki alasan sendiri:

Usulan dari umat tidak terealisasi. Kitakita saja disini yang memikirkan kira-kira program apa yang pas buat masyarakat kita, yang dibutuhkan masyarakat. Dan kegiatan apa kira-kira yang bisa melibatkan masyarakat. Kami kan juga sudah tahu, di rapat-rapat dengan mereka biasanya mereka menyampaikan unek-unek. Kayaknya ini pak Nengah yang bagus diprogramkan. Misalnya kebutuhan guru agama. Kami kan sendiri sudah tahu melalui pengawas kami yang ada di kabupaten/kota...gimana data siswa kita dan guru kita... dari data siswa kami sudah tahu...termasuk juga informasi dari penyuluh (wawancara, 10/4/2013).

Bagi pak Nengah, keterlibatan masyarakat dalam penyusunan program Bimas Hindu tidak dibutuhkan karenaindividu yang ada di Bimas Hindu sudah mengerti sepenuhnya apa yang dibutuhkan oleh masyarakat. Apalagi, jumlah masyarakat Hindu di Provinsi Sulawesi Selatan tidak banyak. Para guru dan penyuluh yang menjadi agen Bimas Hindu di lapangan menjadi sumber informasi yang dapat dijadikan bahan penyusunan program. Artinya, keterlibatan nalar publik lebih banyak direproduksi oleh pejabat Kemenag. Asumsi Pak Nengah tidak sepenuhnya salah. Kepekaan personal dari pejabat negara memang sangat dibutuhkan.

Akan tetapi, dalam konteks supporting service, keterlibatan publik menjadi sangat penting. Pembacaan yang detil terhadap realitas dan kebutuhan masyarakat menjadi modal yang sangat penting dalam pengambilan keputusan. Keterlibatan banyak pihak akan memudahkan lembaga negara untuk menyusun program yang tepat. Apalagi, jangkauan kerja Bimas Hindu Sulawesi Utara 
relatif sangat luas meliputi beberapa kabupaten/ kota. Dengan jumlah tenaga dan sumber dana yang sangat terbatas, keterlibatan publik menjadi sangat niscaya.

Selain itu, keterlibatan banyak pihak akan meminimalisir potensi konflik yang mungkin muncul karena persoalan kebijakan yang salah kaprah. Misalnya, usulan program yang berkaitan dengan dengan tupoksi pendidikan di atas bisa dinilai politis oleh warga jika tidak mendapatkan porsi penjelasan yang lengkap. Program pemberian sertifikasi, workshop, dan peningkatan mutu pendidikan merupakan kegiatan yang bertujuan untuk meningkatkan kualitas dan mutu pendidikan Hindu. Semua ini tidak ada yang salah. Bahkan sudah seharusnya seperti itu. Tetapi, dalam konteks Hindu Sulawesi Utara, bisa dibaca lain. Fakta menunjukkan kalau jumlah guru agama Hindu (PNS) yang ada di Sulut hanya satu orang. Program Bimas Hindu ini bisa jadi tidak menjawab realitas kebutuhan umat Hindu di Manado. Dalam konteks pendidikan, umat Hindu lebih membutuhkan tambahan guru agama, pengadaan sekolah Agama Hindu, dan atau memberi dukungan penuh kepada sekolah minggu dengan memberikan bantuan alat belajar dan honorarium (hal yang terakhir sudah diprogramkan).

Lalu, program pendidikan yang tidak tepat sasaran ini kemudian bisa dibaca politis karena faktanya guru agama Hindu yang berstatus PNS ini adalah kerabat dekat dari pejabat Pembimas. Usulan program pendidikan yang semula dimaksudkan untuk menguatkan kapasitas guru agama bisa dibaca sangat politis. Oleh karena itu, pelibatan publik dalam sebuah forum khusus bisa menjadi ruang yang sehat bagi Bimas Hindu untuk lebih akuntabel. Setidaknya ruang ini bisa menjadi tempat untuk menjelaskan program kerja yang disusun.

Pelibatan publik tentu saja bukan bagian dari bentuk intervensi publik terhadap negara dalam hal pengambilan keputusan. Dan memang, mekanisme kerja Kementerian Agama khususnya Bimas Hindu tidak mensyaratkan pelibatan publik. Tetapi, satu hal yang sangat penting untuk disadari adalah kehadiran sebuah unit kerja Kementerian Agama adalah representasi dari kehadiran umat. Tidak mungkin ada Bimas Hindu jika tidak ada umat Hindu di Sulawesi Utara. Kehadiran publik menjadi persyaratan dari kehadiran unit kerja. Dengan logika seperti itu, pelibatan publik dalam pengambilan keputusan dalam Kementerian Agama adalah juga sangat logis.

\section{Tanggapan Masyarakat Hindu}

Ada ungkapan menarik dari Ketut Dewa Anom, "Sebenarnya bagi masyarakat kami, tanpa $k \backslash$ Kementerian Agama, tanpa parisada (ormas), warga tetap bisa menjalankan agamanya. (wawancara Dewa Anom, 21/4/2013). Ungkapan ini adalah refleksi dari pemahaman bahwa agama adalah persoalan personal yang tidak perlu mendapatkan intervensi apapun dari negara. Ini benar, karena soal-soal yang menjadi fokus kerja Kementerian Agama melalui Bimas sebagian besar memang sudah dilakukan secara mandiri oleh warga. Misalnya pengelolaan ibadah dilakukan sepenuhnya oleh pemangku (sebutan untuk pimpinan spritual Hindu di Manado). Pendidikan agama pun demikian dilakukan secara mandiri oleh masyarakat Hindu di Pura. Apalagi, pelayanan pernikahan, kelahiran, dan kematian semuanya yang memang tidak menjadi agenda Kementerian Agama.

Tentu saja ini bukan bagian dari pemikiran yang subversif. Ini bisa jadi bentuk dari tidak "terangnya" peran Kementerian Agama dalam mengelola kebutuhan keagamaan warganya sebagai akibat dari model pelayanan yang bersifat supporting. Warga tidak merasakan kehadiran Kemenag sebagai jalur negara yang bisa menguatkan spiritualitas mereka.

Lalu apakah itu berarti peran Kementerian Agama benar-benar tidak signifikan? Saya kira juga tidak. Fakta menunjukkan kalau kehadiran sekolah minggu adalah inisiasi dari "orang Kemenag". Pak Ketut Agung Sutiase sebagai Pembimas Hindu pertama di Kemenag Sulut (yang kala itu masih bernama Departemen Agama) bersama dengan Pak Nengah (Ketua Parisada pertama) mengambil inisiatif untuk membuka sekolah minggu yang digilir di rumah-rumah warga sebagai bentuk keprihatinan terhadap anak-anak Hindu yang tidak mendapatkan pendidikan agama secara formal di sekolah. Dan saat ini, yang menjadi tenaga pengajar di Sekolah Minggu adalah orang-orang dari Bimas Hindu.

Sebagai unit kerja yang mengembangkan sistem supporting service, manfaat kehadiran Bimas dan Penyelenggara Hindu dirasakan oleh kelompokkelompok yang menjadi agen. Guru honorer yang mengabdi di Sekolah Minggu, penyuluh non PNS, dan lembaga keagamaan yang ada dalam tubuh masyarakat Hindu Sulawesi Utara mendapatkan manfaat dari program Kementerian Agama, baik bersifat finansial seperti insentif bulanan, bantuan pengembangan organisasi, rumah ibadah maupun yang bersifat pengembangan kapasitas seperti 
workshop dan ruang untuk ceramah di radio dan TV lokal.

Putu Manuaba mengakui sering mendapatkan bantuan finansial dari Kementerian Agama untuk mendukung siar agama Hindu melalui buletin. Meski bantuan itu berasal dari Direktorat Jenderal Bimas Hindu Kemenag RI bukan program Bimas Hindu. Dewa Indrayani, salah seorang pengurus dan aktivis KMHDI juga mengaku mendapatkan manfaat dari program Kemenag melalui workshop pemberdayaan organisasi kemahasiswaan atau donasi yang bersifat insidentil untuk membiayai program organisasinya. Artinya, out put kinerja Kementerian Agama melalui Bimas dan Penyelenggara Hindu telah dirasakan oleh masyarakat Hindu melalui agen yang menjadi sasaran sasaran pelayanan program Kementerian Agama. Dengan begitu, Bimas dan Penyelenggara Hindu sudah cukup baik menjalankannya perannya sebagai lembaga supporting service.

Hal yang dirasakan kurang adalah komunikasi antara organisasi publik seperti Parisada dan kementerian dalam hal pengambilan keputusan yang berkaitan dengan kepentingan masyarakat Hindu. Misalnya penetapan penyuluh agama honorer atau non-PNS. Tokoh agama Hindu mengeluhkan sistem penetapan penyuluh agama tanpa melalui komunikasi yang baik dengan otoritas warga yang direpresentasi oleh Parisada. Seperti yang diungkapkan oleh salah seorang narasumber:

Bukannya kita mau mengintervensi atau mengambil alih peran Kemenag ya. Tapi kan faktanya yang paling tahu siapa yang berperan selama ini kan kita-kita di Parisada. Kita tahu siapa yang rajin ke Pura dan terlibat dalam kegiatan-kegiatan keagamaan Hindu. Kita maunya, penyelenggara atau Bimas itu koordinasi dengan kita. Dorang maunya berapa penyuluh. Kita yang pilih. Sebab, kita tidak ingin sembarang menunjuk orang jadi penyuluh padahal kita belum tahu kapasitasnya. Nanti kalau miring-miring sedikit. Kan bahaya juga untuk warga kita. Nah, sekarang ini katanya ada penyuluh PNS yang diangkat oleh kementerian tapi sampai sekarang saya sendiri tidak tahu siapa penyuluhnya itu.

Informan ini menyadari dengan baik kalau publik tidak bisa 'ikut campur' dalam urusan Kementerian Agama. Kementerian Agama memiliki otoritas khusus untuk menentukan kebijakannya sendiri tanpa harus mendapatkan masukan atau pertimbangan dari lembaga di luar negara. Persoalannya adalah "publik" yang ingin dilayani adalah publik yang sama yaitu warga Hindu. Dan publik yang sama itu telah memiliki struktur sosial dan nilai sendiri yang tidak bisa dengan mudah diubah begitu saja. Permintaan untuk ikut "menentukan" siapa yang menjadi penyuluh misalnya adalah strategi agar negara tidak dengan seenaknya mengatur publik. Bagi Parisada, mereka adalah arus mainstream. Teologi mainstream warga yang berhaluan Siwa Sidanta harus dijaga dan dipelihara. Penyuluh yang dipilih adalah benarbenar penyuluh agama yang mengerti arus teologi itu. Itulah yang dimaksud miring-miring sedikit oleh informan di atas.

Faktanya, warga Hindu di Manado memang tidak hanya berbasis Siwa Sidanta. Di luar itu, ada beberapa kelompok kecil yang mengakomodasi diri dalam aliran-aliran keagamaan non mainstream seperti Hari Krishna dan Sai Baba. Informan diatas sejatinya mengkhawatirkan kalau orang-orang yang diangkat menjadi penyuluh adalah berasal dari aliran tertentu lalu bertugas melakukan penyuluhan agama kepada warga yang punya aliran teologi yang berbeda. Hal ini dikhawatirkan akan menimbulkan kebingungan warga, dan pada tingkat tertentu akan memunculkan konflik internal.

\section{PENUTUP}

Berdasarkan temuan lapangan, bahwa asumsi dasar penelitian yang menganggap kelompok minoritas biasanya kesulitan untuk mengekspresikan wajah spiritualitas mereka relatif terbantahkan. Masyarakat Hindu di Kota Manado adalah potret dari masyarakat minoritas yang ceria dan gembira. Mereka tidak pernah punya masalah dengan pendirian rumah ibadah atau hal lain yang berkaitan dengan isu keagamaan. Asumsi ini mulai kembali terlihat ketika siswa Hindu Manado kesulitan untuk mendapatkan pelajaran agama di sekolah formal, dan kadang-kadang terabaikan ketika menghadapi ujian nasional. Kenyataan jumlah yang sedikit itu membuat mereka terabaikan atau dianggap tidak penting. Hal ini juga terlihat dari pengaturan unit kerja yang sama sekali tidak tepat sasaran. Kehadiran Penyelenggara Bimas Hindu di Kota Manado tidak tepat karena ada tempat lain yang lebih membutuhkan yaitu di Kabupaten Bolmong, basis umat Hindu di Sulawesi Utara.

Pengabaian struktural pun semakin terlihat ketika struktur penyelenggara Bimas Hindu/ Buddha tidak dipisahkan meski telah ada peraturan baru PMA No. 13 tahun 2012. Penyatuan unit kerja Hindu/Buddha bagaimanapun juga adalah sesuatu yang tidak benar. Dua agama ini berbeda 
dan seharusnya diperlakukan berbeda. Orang Hindu yang menjadi pimpinan unit kerja tentu saja memiliki keterbatasan dalam melayani orang Buddha demikian pula sebaliknya. Jenis pelayanan Pembimas bersifat supporting service, agensi, tidak melayani warga secara langsung. Representasi pelayanan Kemenag dilakukan oleh guru agama Hindu, penyuluh agama, dan lembaga keagamaan.

Secara umum, Pelayan Kemenag (melalui Bimas dan Penyelenggara Hindu) secara umum sudah berjalan dengan baik. Kedua unit kerja ini bekerja untuk memenuhi tugas pokok dan fungsi (tupoksi). Program kerja yang disusun setiap tahunnya dimaksudkan untuk memenuhi tupoksi pendidikam dan urusan agama Hindu (selain fungsi administrasi). Problemnya adalah soal transparansi dan partisipasi. Publik Hindu sebagai stakeholder sejauh ini tidak mengetahui dengan baik hal-hal apa yang menjadi program kerja yang diprogramkan oleh Kemenag. Ini karena partisipasi publik dalam penyusunan ataupun dalam pengambilan keputusan tidak terjadi. Kemenag "menjauhkan diri” dari publik karena menganggap sudah tahu apa yang dibutuhkan oleh publik. Kemenag hanya mengembangkan sistem yang bersifat empati dalam teori Fitsimmons.

Padahal, sebagai lembaga yang mengembangkan supporting service, keterlibatan publik melalui lembaga keagamaan publik sangat niscaya diperlukan. Lembaga keagamaan Hindu secara umum telah merasakan manfaat dari pelayanan negara melalui pembimas. Program Kemenag ikut mendorong penyebaran syiar Agama Hindu melalui media lokal, bantuan fisik, dan suplemen gaji untuk para penyuluh nonPNS. Problem yang dikeluhkan oleh publik Hindu adalah kurangnya komunikasi dan koordinasi antara Pembimas Hindu dan Parisadah (sebagai representasi umat Hindu). Padahal, koordinasi antara dua lembaga ini sangat mutlak diperlukan karena keduanya "bekerja" untuk publik yang sama.

\section{UCAPAN TERIMA KASIH}

Penelitian ini terlaksana berkat bantuan dan dukungan berbagai pihak. Peneliti mengucapkan terimakasi Kepada Kepala Balitbang Agama Makassar, rekan-rekan peneliti dan informan yang telah terlibat dalam penelitian ini mulai pembahasan desain penelitian hingga pengumpulan data lapangan. Terimkasih penulis ucapkan kepada Pak Nengah Kokog, Pak Made Suda, Ketut Dewa Anom, Ni Kadek Novianti, Pak Ida Bagus Putu Wedha Manuaba, Ida Bagus Ketut Alit, Tjok Trisnawati,
Ketut Surtha, Dewa Ayu Indrayani, dan Masyarakat Hindu Kota Manado serta semua pihak yang terlibat dalam pelaksanaan penelitian ini.

\section{DAFTAR PUSTAKA}

KMA 373 tahun 2002 tentang struktur Penyelenggara Bimas Hindu/Buddha di Kementerian Agama.

LAKIP (Laporan Akuntabilitas Kinerja Instansi Pemerintah) Bimas Hindu Kementerian Agama Kota Manado, tahun 2012.

LAKIP (Laporan Akuntabilitas Kinerja Instansi Pemerintah) Bimas Hindu Kementerian Agama Wilayah Provinsi Sulawesi Selatan, tahun 2011.

Manado Post. Hari Nyepi di Dumoga Khusyu'; Jalan Desa Ditutup, Umat Lain Ikut Menjaga tanggal 13 Maret 2013.

Pat Badrun dkk., 2008. Optimalisasi Pelayanan Keagamaan Departemen Agama. Makassar. Indobis Publishing.

PBM No.9 dan 8 Tahun 2006 Tentang Pedoman Pelaksanaan Tugas Kepala Daerah/Wakil Kepala Daerah dalam Pemeliharaan Kerukunan Umat Beragama, Pemberdayaan Forum Kerukunan Umat Beragama, dan Pendirian Rumah Ibadat.

Pembimas Hindu Kanwil Kemenag Provinsi Sulawesi Utara, tahun 2012.

PMA No. 13 tahun 2012 tentang struktur Penyelenggara Bimas Hindu/Buddha di Kementerian Agama.

Ratminto dan Atik SP. 2007. Manajemen pelayanan, Pengembangan Model Konseptual, Penerapan Citizen's Charter dan Standar pelayanan Mutu. Jogjakarta. Pustaka Pelajar.

Rencana Kinerja Bimas Hindu Kementerian Agama Wilayah Provinsi Sulawesi Utara, tahun 2012.

Tim Peneliti Balai Litbang Agama. 2011. Spirit Agama Khonghucu. Jakarta: Orbit.

Tim Peneliti Bid. Kehidupan Beragama. 2011. Mengukur Indeks Kerukunan Antar Umat Beragama di Sulawesi Utara. Laporan Penelitian Balai Litbang Agama Makassar.

Sanderson, Stephen K. 2000. Makro Sosiologi: Sebuah Pendekatan Terhadap Reaslitas Sosial, Jakarta. PT. RajaGrafindo Persada.

Undang-Undang RI Nomor 25 Tahun 2009 tentang pelayanan Publik. 